\title{
УДК 336.2
}

https://doi.org/10.52058/2786-5274-2022-2(4)-143-151

Безручук Світлана Леонідівна кандидат економічних наук, доцент кафедри інформаційних систем в управлінні та обліку, Державний університет «Житомирська політехніка», вул. Чуднівська, 103, м. Житомир, 10005, тел.: (093) 358-23-22, https://orcid.org/0000-0001-7374-7875

Голіченко Дар'я Володимирівна студентка 4-го курсу групи ОО-3 факультету бізнесу та сфери обслуговування Державного Університету «Житомирська Політехніка», вул. Чуднівська, буд. 103, м. Житомир, 10025 , тел.: (063) 677-83-50, https://orcid.org/0000-0002-4927-0349.

\section{КРИТЕРІЇ РИЗИКОВОСТІ ПЛАТНИКІВ ПОДАТКІВ В АСПЕКТІ СУДОВИХ СПРАВ}

Анотація: Податки $\epsilon$ складною й надзвичайно впливовою на всі економічні явища та процеси фінансовою категорією. На сьогодні роль податків як регулятора економіки зростає. А лідером серед них постає податок на додану вартість, тому що несе третину податкових надходжень до бюджету.

Впровадження податкового законодавства тягне за собою низку суперечностей, як внутрішніх, так i зовнішніх. Досить часто суперечності виникають щодо визначення критеріїв ризиковості платників податків.

В Постанові Кабінету Міністрів України від 11.12.2019 р. № 1165 визначено 8 критеріїв ризиковості суб'єктів господарювання, які виступають платниками. На основі цих критеріїв податкові органи можуть відносити підприємства до ризикової групи. Головною вимогою являється тільки те, що для такого вердикту, контролюючим органам, необхідно надати досить обгрунтованих доказів, а не просто звинувачення. В свою чергу, самим підприємствам потрібно буде досить уважно все проаналізувати та надати у відповідь, для свого порятунку з ризикової групи, всі можливі документи, які підтверджують правильність здійснення господарської операції: матеріальну базу для цього, основні засоби, обладнання, штатний розпис, складське приміщення та інше.

В статті більш детально розписані суперечності податкового законодавства, також наведено перелік восьми критеріїв ризиковості платника податків та розглянуто п'ять судових справ, щодо віднесення підприємств до ризикових груп 3 їх рішеннями. В основному під ризиковість відносять товариства, спираючись на восьмий пункт Критеріїв, причому податкові органи надають не досить розгорнуті пояснення такого рішення. Тому, зазвичай, платник податків виграє такі судові справи, надаючи повний пакет документальних доказів по підприємству. 
Ключові слова: податок на додану вартість, критерії ризиковості платників податків, ризикова група, судові справи, платник податків, контролюючі органи.

Bezruchuk Svetlana Leonidivna PhD in Economics, as. prof., Zhytomyr Polytechnic State University, Chudnivska St., 103, Zhytomyr, 10005, tel.: (093) 358-23-22, https://orcid.org/0000-0001-7374-7875

Holichenko Darya Volodymyrivna 4th year student of the OO-3 group of the Faculty of Business and Service of the Zhytomyr Polytechnic State University, Chudnivska St., 103, Zhytomyr, 10005, tel.: (063) 677-83-50, https://orcid.org/0000-0002-4927-0349

\section{CRITERIA OF RISK OF TAXPAYERS IN THE ASPECT OF JUDICIAL CASES}

Abstract. Taxes are a complex and extremely influential financial category in all economic phenomena and processes. Today, the role of taxes as a regulator of the economy is growing. And the leader among them is the value added tax, because it carries a third of tax revenues to the budget.

The implementation of tax legislation entails a number of contradictions, both internal and external. Quite often disagreements arise over the definition of risk criteria for taxpayers.

The Resolution of the Cabinet of Ministers of Ukraine of December 11, 2019 № 1165 defines 8 risk criteria for business entities that act as payers. Based on these criteria, the tax authorities may classify enterprises as at risk. The main requirement is only that for such a verdict, the supervisory authorities need to provide sufficiently substantiated evidence, not just accusations. In turn, the companies themselves will need to carefully analyze everything and provide in response, to save themselves from the risk group, all possible documents confirming the correctness of the business transaction: material base, fixed assets, equipment, staffing, warehouse and other.

The article describes in more detail the contradictions of tax legislation, also lists eight risk criteria for taxpayers and considers five lawsuits to classify companies as at risk with their decisions. Companies are mainly at risk based on the eighth point of the Criteria, and the tax authorities do not provide sufficiently detailed explanations of this decision. Therefore, as a rule, the taxpayer wins such lawsuits by providing a complete package of documentary evidence on the company.

Keywords: value added tax, risk criteria of taxpayers, risk group, court cases, taxpayer, regulatory authorities.

Постановка проблеми. Вивчення сучасних проблем розвитку підприємств набуває більших обертів. Досить часто підприємства мають проблеми через 
ухилення від сплати податків. Саме це відносить їх до ризикової групи платників, що слугує великим каменем спотикання для бізнесу, особливо коли справа переходить до суду.

Одними із ключових аспектів роботи контролюючих органів щодо зменшення злочинів зі сплати податків є встановлення критеріїв ризиковості платників податків. За допомогою змістовності таких критеріїв, буде залежати контроль перевірок податкових органів та рівень додаткових надходжень податків і зборів до бюджету країни.

Аналіз останніх досліджень і публікацій. Багато вітчизняних вчених у своїх дослідженнях поширюють питання щодо процесів обліку з ПДВ в професійній літературі, це зокрема праці О. Коваленко [1], О. Оксенюк [2], І. Рябець [3], О. Папиріної [4], Н Яновської [5], Л. Солошенко [6], В Карпової [7;8], Н. Кузнецової [9], Н. Адамович [10], С. Сокотенюк [11] та ін., а також зарубіжних вчених Дж. Кейнса [12], П. Самуельсона [13], М. Малгожата [14], М.Текрей та А. Канар [15], М.Абузарова [16], К.Уолш [17] та ін. Вони мають особливу цінність, оскільки можуть бути використані платниками ПДВ юридичними і фізичними особами.

Мета статті. Метою статті $є$ проведення аналізу судових справ щодо визначення критеріїв ризиковості платників податків.

Викладення основного матеріалу. Впровадження податкового законодавства тягне за собою низку суперечностей, як внутрішніх, так i зовнішніх. Вони в свою чергу значно занижують продуктивність систем оподаткування, як наслідок це шкодить і контролюючим органам, і платникам податків.

По-перше, вирішальним чинником при реформування податкової системи слугує фіскальна спрямованість, разом 3 тим ऑï регулююча функція - не зорієнтована на стале економічне зростання. Таким чином, існує і постійно поглиблюється протиріччя між інтересами держави (в частині виконання фіскальної функції) і суб'єктами підприємницької діяльності.

По-друге, структура оподаткування тягне за собою неправильне розподілення навантаженості: на виробництво - високе, а природні ресурси низьке, що робить іï несприятливою для розвитку економіки.

По-третє, в Україні досить мінлива нормативно-правова база у сфері оподаткування, а окремі законодавчі акти - недостатньо узгодженими між собою. Так, чимало правових документів мають неоднозначне або недостатньо визначене тлумачення, що призводить до викривлень i порушень при їх застосуванні, і суттєвого зниження привабливості української економіки для зарубіжних інвесторів [18].

Розглянемо ж законодавство щодо критеріїв ризиковості.

Велика можливість потрапити до ризикової групи блокування, є не тільки у підприємств, які займаються махінаціями, але й у добросовісних підприємців. I це безсумнівно одна 3 найболючіших тем платників податків. 
Потрапляння платників під критерії ризиковості ПДВ насьогодні є досить поширеним, про що свідчить велика кількість спорів у досудовому та судовому порядках.

Постановою Кабінету Міністрів України від 11.12 .2019 р. № 1165 визначено 8 критеріїв ризиковості платників ПДВ:

1.Реєстрація на підставі недійсних (втрачених, загублених) та підроблених документів.

2.Реєстрація на вигаданих, померлих, безвісти зниклих осіб.

3.Реєстрація особами, що не мали наміру провадити фінансовогосподарську діяльність.

4.Платника податку зареєстровано (перереєстровано) та ним впроваджено фінансово-господарську діяльність без відома i згоди його засновників i призначених у законному порядку керівників.

5.Платник - юридична особа не має відкритих рахунків у банківських установах.

6.Платник ПДВ не подав податкової звітності з ПДВ за два останніх звітних (податкових) періоди.

7.Платник податку на прибуток підприємств не подав фінансової звітності за останній звітний період.

8.У контролюючих органах наявна податкова інформація, яка стала відома у процесі провадження поточної діяльності під час виконання покладених на контролюючі органи завдань і функцій, що визначає ризиковість здійснення господарської операції, зазначеної в поданих для реєстрації податковій накладній. [19]

Останнім часом податкові органи, при віднесенні платника до ризикової групи, посилаються на восьмий пункт Критеріїв. Адже звертаючись до цього пункту, податкові органи можуть на будь-якій підставі віднести платника до ризикового статусу, а саме: придбання та реалізація товарів (послуг) у постачальників/ покупцям 3 ризиковим статусом, недостатня кількість матеріалів чи працівників для виготовлення товару чи надання послуги, недостатня кількість обладнання чи транспорту, чи взагалі незрозумілі схеми придбання товару у постачальників, які не відслідковуються та інше. Рідше трапляються випадки, коли потрапляння до ризикової групи відбуваються через неподання фінансової чи податкової звітності та відсутності банківського рахунку.

Якщо ж вже сталося, що платник потрапив під критерії ризиковості, то він має право звернутися до комісії регіонального рівня з вимогою про виключення його зі списку ризикових, надавши докази про свою невинність. Далі, він має право у порядку адміністративного оскарження звернутися до органів ДПС України, але іноді це виявляється неефективним.

Надалі платник для захисту своїх прав звертається до суду з оскарженням рішення про включення до переліку ризикових. 
Якщо ж податкові органи включають платника податків до ризикової групи без належних обгрунтувань, а як показує практика вони зазвичай не розшифровують зміст підстави для висновку ризиковості, то такій підхід не можна вважати чинним, за позицією судів. Підставу для віднесення платника до списку ризикових необхідно достеменно, чітко та конкретизовано розписати. Адже саме з цієї інформації платник буде знати конкретний перелік документів та пояснень для свого порятунку, тобто виключення з цього списку[20].

Прикладом вищесказаного може слугувати Постанова Верховного Суду від 05.01.2021 у справі № 640/11321/20. У ній зазначено, що комісії контролюючого органу необхідно надати обгрунтування на підставі якої інформації вона дійшла до висновку, що Товариство 3 обмеженою відповідальністю «Лотос Юніон» необхідно включити до переліку платників податків, які відповідають критеріям ризиковості платника податку, та додати достеменні докази цієї інформації [21].

Схожа ситуація відбулася ще й у Постанові Верховного Суду від 22.07.2021 у справі № 520/480/20. У ній зауважено, що посилання ГУ ДПС не може свідчити про відповідність критеріям правомірності, лише на аналізі діяльності платника без належного документального обгрунтуванням [22].

У справі № 160/4272/21 було віднесено ТОВ “Соланта Інжиніринг Груп” до ризикової групи грунтуючись на співпраці з сумнівними контрагентами, на що Судом було прийнято рішення на користь платника, через недостатню кількість наданих доказів, адже у комерційній діяльності виконання послуг не завжди потребує наявності основних засобів, великої кількості персоналу, оскільки можливе укладання договір оренди чи найму [23].

Відсутність трудових ресурсів привела ТОВ «ТМК ЦЕНТР» також до судової справи. Платник успішно виграв справу довівши, що потреби підприємства повність задовольняються наявною кількість працівників, а також складськими приміщеннями та матеріальною базою [24].

А у справі № 420/8714/21, у якій ПП «Брок Торг» також підлягав до потрапляння у ризикову групу через співпрацю з сумнівними контрагентами, П'ятий апеляційний адміністративний суд також підтримав платника. Вказавши на те, що до відповідальності повинно бути притягнутим підприємство у разі порушення самого платника, а не через його зв’язки з іншими [25].

Висновки. Віднесення до ризикової групи безсумнівно критична ситуація, адже це тягне за собою низку неприємності для підприємства, як приклад блокування податкових накладних, на розблокування яких необхідно докласти багато сили та часу, а також це руйнує відносини 3 клієнтами, які вже 3 побоюванням відносяться до співпраці, або й зовсім відмовляються.

На основі дослідженого ми дійшли до таких висновків, що система моніторингу податкової відповідальності явно потребує значних удосконалень. Ризик потрапити до ризикової групи є не тільки у платників, які займаються махінаціями, а й у добросовісних підприємств. Тому товариствам потрібно 
завжди бути готовими доводити свою позицію та надавати всі можливі докази, щоб спростувати свою позицію ризикового підприємства. Варто також більш ретельно обирати контрагентів, з якими співпрацювати, щоб через їх сумнівний статус також не потрапити до ризикової групи.

Як підсумок зазначимо, що встановленні державою критерії ризиковості $€$ досить неконкретними, що мають негативний вплив для розвитку суб'єктів господарювання. За допомогою них, податкові органи можуть 3 легкістю включити підприємства до ризикових. Необхідно більш точніше розписати кожен пункт з Критеріїв, а особливо пункт 8, на який найчастіше спираються контролюючі органи.

\section{Лimepamypa:}

1. Коваленко О. Нова форма податкової накладної - нові правила ії заповнення. Все про бухгалтерський облік. 2017. № 25. С. 3-8.

2. Оксенюк О. І. Фіскальна ефективність податку на додану вартість в економіці України : дис. канд. екон. наук : 08.00.08 / Оксана Ігорівна Оксенюк.

3. Рябець І. Л. Організаційно-правові проблеми відшкодування ПДВ в Україні. Боротьба 3 організованою злочинністю і корупцією (теорія і практика). 2010. № 23. С. 259-264.

4. Папиріна О. ПДВ-документи: у вирі березневих змін. Бухгалтерія. 2017. №11.

5. Яновська Н. Безоплатна передача: схоже, податківці знову хочуть два ПЗ з ПДВ. Податки та бухгалтерський облік. 2017. № 17.

6. Солошенко Л. «Умовні» ПЗ за п. 198.5 ПКУ (при неоподатковуваному/ негосподарському використанні). Податки та бухгалтерський облік. 2016. № 64.

7. Карпова В. «Компенсуючі» податкові зобов’язання за п. 198.5 ПКУ: загальна процедура. ТОВ "Інформаційно-аналітичний центр "ЛІГА", ТОВ "ЛІГА ЗАКОН", БУХГАЛТЕР \& ЗАКОН. 09.11.2015. № 45 (401).

8. Карпова В. «Компенсуючі» податкові зобов'язання за п. 198.5 ПКУ: документальне оформлення й облік. ТОВ "Інформаційно-аналітичний центр «ЛІГА», ТОВ «ЛІГА ЗАКОН», БУХГАЛТЕР \& ЗАКОН. 09.11.2015. № 45 (401).

9. Кузнецова Н. Розрахунок коригування до податкової накладної: заповнюємо порядково. [Електронний ресурс] - Режим доступу: https://uteka.ua/ua/publication/Raschetkorrektirovki-k-nalogovoj-nakladnojzapolnyaem-postrochno.

10. Адамович Н. Заповнюємо «новенький» розрахунок коригування. Податки та бухгалтерський облік. 2016. № 20.

11. Сокотенюк С. Особливості прийняття та застосування електронного адміністрування пдв в україні. Електронний журнал: Ефективна економіка № 3, 2016.

12. Кейнс Дж. М. Общая теория занятости, процента и денег. М.: Прогресс, 1978 г.

13. Самуельсон П. «Економика» (1948р.), Том 1. [Електронний ресурс] - режим доступу: http://www.bibliotekar.ru/biznes-64/.

14. Hybka M. (2018). Krajowe obszary ryzyka zewnętrznego jako kryterium selekcji podatników vat do kontroli podatkowych. Prace naukowe uniwersytetu ekonomicznego we Wrocławiu, Vol. 509. S. 110-121.DOI:10.15611/pn.2018.509.09

15. Mick Thackray i Kanar Ahmed (2018). Program Analizy Luk Administracji Skarbowej - Luka w podatku od towarów i usług. International Monetary Fund. MFW Raport Krajowy Nr 18/357.

16. Marta Abuzarova (2014). Polskie nazwiska mieszkańców Drohobycza końca XVIII i początku XIX wieku na tle wschodniosłowiańskim. [Online], available at: https://repozytorium.amu.edu.pl/bitstream/10593/10991/1/M.\%20Abuzarowa.\%20Praca\%20doktor ska\%20\%2B\%20streszczenie.pdf. 
17. Chris Walsh (2019). Global value added tax risk management. [Online], available at:: https://rsmus.com/what-we-do/services/tax/indirect-tax/value-added-tax/global-vat-riskmanagement.html.

18. Крушельницька Т. Суперечності у сфері державного управління податковою системою та напрями їх вирішення. Механізми державного управління. ст. 79-85.

19. Про затвердження порядків 3 питань зупинення реєстрації податкової накладної/розрахунку коригування в Єдиному реєстрі податкових накладних: Постанова Кабінету Міністрів України від 11 грудня 2019 р. № 1165. [Електронний ресурс] - режим доступу: https://zakon.rada.gov.ua/laws/show/1165-2019-\%D0\%BF\#Text

20. Хиляк I., Яцків М. Концепція “ризиковий платник”: нюанси статусу та варіанти поведінки. Вісник про податки. [Електронний ресурс] - режим доступу: http://www.visnuk.com.ua/uk/news/100028462-kontseptsiya-rizikoviy-platnik-nyuansi-statusu-tavarianti-povedinki.

21. Постанова Верховного Суду від 05.01.2021 у справі № 640/11321/20 [Електронний pecypc] - режим доступу: https://verdictum.ligazakon.net/document/94022453.

22. Постанова Верховного Суду від 22.07.2021 у справі № № 520/480/20 [Електронний peсурс] - режим доступу: https://verdictum.ligazakon.net/document/98493729.

23. Судова справа № 160/4272/21 [Електронний ресурс] - режим доступу: https://vkursi.pro/vsudi/decision/95809672.

24. Судова справа № 420/7340/21 [Електронний ресурс] - режим доступу: https://vkursi.pro/vsudi/decision/96795462.

25. Судова справа № 420/8714/21 [Електронний ресурс] - режим доступу: https://verdictum.ligazakon.net/document/97274817.

\section{References:}

1. Kovalenko, O. (2017). Nova forma podatkovoï nakladnoï - novi pravila ïi zapovnennja [A new form of tax invoice - new rules for filling it out]. Vse pro buhgalters'kij oblik - All about accounting, 25, 3-8 [in Ukrainian].

2. Oksenjuk, O. I. Fiskal'na efektivnist' podatku na dodanu vartist' v ekonomici Ukraïni [Fiscal efficiency of value added tax in the economy of Ukraine]. Candidate's thesis. [in Ukrainian].

3. Rjabec', I. L. (2010). Organizacijno-pravovi problemi vidshkoduvannja PDV v Ukraïni [Organizational and legal issues of VAT refund in Ukraine]. Borot'ba z organizovanoju zlochinnistju i korupcicju (teorija i praktika) - Fight against organized crime and corruption (theory and practice), 23, 259-264 [in Ukrainian].

4. Papirina, O. (2017). PDV-dokumenti: u viri bereznevih zmin [VAT documents: in the vortex of March changes]. Buhgalterija - Accounting, 11 [in Ukrainian].

5. Janovs'ka, N. (2017). Bezoplatna peredacha: shozhe, podatkivci znovu hochut' dva PZ z PDV [Free transfer: it seems that the tax authorities again want two software with VAT]. Podatki ta buhgalters'kij oblik - Taxes and accounting, 17 [in Ukrainian].

6. Soloshenko, L. (2016). «Umovni» PZ za p. 198.5 PKU (pri neopodatkovuvanomu/negospodars'komu vikoristanni) ["Conditional" software under paragraph 198.5 of the TCU (for non-taxable / non-economic use)]. Podatki ta buhgalters'kij oblik - Taxes and accounting, 64 [in Ukrainian].

7. Karpova, V. (2015). «Kompensujuchi» podatkovi zobov'jazannja za p. 198.5 PKU: zagal'na procedura. TOV "Informacijno-analitichnij centr "LIGA", TOV "LIGA ZAKON" ["Compensating" tax liabilities under paragraph 198.5 of the TCU: general procedure. LLC "Information and Analytical Center" LEAGUE ", LLC" LEAGUE LAW "]. BUHGALTER \& ZAKON - ACCOUNTANT \& LAW, 45 (401) [in Ukrainian]. 
8. Karpova, V. (2015). «Kompensujuchi» podatkovi zobov'jazannja za p. 198.5 PKU: zagal'na procedura. TOV "Informacijno-analitichnij centr "LIGA", TOV "LIGA ZAKON" ["Compensating" tax liabilities under paragraph 198.5 of the TCU: general procedure. LLC "Information and Analytical Center" LEAGUE ", LLC" LEAGUE LAW "]. BUHGALTER \& ZAKON - ACCOUNTANT \& LAW, 45 (401) [in Ukrainian].

9. Kuznecova, N. Rozrahunok koriguvannja do podatkovoï nakladnoï: zapovnjuemo porjadkovo. [Calculation of adjustments to the tax invoice: fill in the order]. uteka.ua Retrived from https://uteka.ua/ua/publication/Raschet-korrektirovki-k-nalogovoj-nakladnojzapolnyaempostrochno [in Ukrainian].

10. Adamovich, N. (2016). Zapovnjuєmo «noven'kij» rozrahunok koriguvannja [Fill in the "new" calculation of the adjustment]. Podatki ta buhgalters'kij oblik - Taxes and accounting, 20 [in Ukrainian].

11. Sokotenjuk, S. (2016). Osoblivosti prijnjattja ta zastosuvannja elektronnogo administruvannja pdv $\mathrm{v}$ ukraïni [Features of the adoption and application of electronic VAT administration in Ukraine]. Efektivna ekonomika - Effective Economics, 3, 2016 [in Ukrainian].

12. Kejns Dzh., M. (1978). Obshhaja teorija zanjatosti, procenta i deneg [General theory of employment, interest and money]. M.: Progress [in Russian]

13. Samuel'son, P. (1948). «Ekonomika» ["Economics"]. www.bibliotekar.ru Retrived from http://www.bibliotekar.ru/biznes-64/ [in Ukrainian].

14. Hybka M. (2018). Krajowe obszary ryzyka zewnętrznego jako kryterium selekcji podatników vat do kontroli podatkowych. Prace naukowe uniwersytetu ekonomicznego we Wrocławiu, Vol. 509. S. 110-121.DOI:10.15611/pn.2018.509.09

15. Mick Thackray i Kanar Ahmed (2018). Program Analizy Luk Administracji Skarbowej - Luka w podatku od towarów i usług. International Monetary Fund. MFW Raport Krajowy Nr 18/357.

16. Marta Abuzarova (2014). Polskie nazwiska mieszkańców Drohobycza końca XVIII i początku XIX wieku na tle wschodniosłowiańskim. [Online], available at: https://repozytorium.amu.edu.pl/bitstream/10593/10991/1/M.\%20Abuzarowa.\%20Praca\%20doktor ska\%20\%2B\%20streszczenie.pdf.

17. Chris Walsh (2019). Global value added tax risk management. [Online], available at:: https://rsmus.com/what-we-do/services/tax/indirect-tax/value-added-tax/global-vat-riskmanagement.html

18. Krushel'nic'ka, T. Superechnosti u sferi derzhavnogo upravlinnja podatkovoju sistemoju ta naprjami ïh virishennja [Contradictions in the field of public administration of the tax system and directions of their solution]. Mehanizmi derzhavnogo upravlinnja - Mechanisms of public administration, 79-85 [in Ukrainian].

19. Postanova Kabinetu Ministriv Ukraïni 'Pro zatverdzhennja porjadkiv z pitan' zupinennja re€straciï podatkovoï nakladnoï/rozrahunku koriguvannja v Cdinomu reestri podatkovih nakladnih" [Resolution of the Cabinet of Ministers of Ukraine "On approval of procedures for suspension of registration of a tax invoice / calculation of adjustments in the Unified Register of Tax Invoices"]. (n.d.). zakon.rada.gov.ua Retrieved from https://zakon.rada.gov.ua/laws/show/ 1165-2019-\%D0\%BF\#Text [in Ukrainian].

20. Hiljak, I., Jackiv M. Koncepcija "rizikovij platnik": njuansi statusu ta varianti povedinki [The concept of "risk payer": the nuances of status and behavior]. Visnik pro podatki. Bulletin of taxes. www.visnuk.com.ua Retrieved from http://www.visnuk.com.ua/uk/news/ 100028462-kontseptsiya-rizikoviy-platnik-nyuansi-statusu-ta-varianti-povedinki [in Ukrainian].

21. Postanova Verhovnogo Sudu vid 05.01.2021 u spravi № 640/11321/20 [Resolution of the Supreme Court of 05.01.2021 in case № 640/11321/20]. verdictum.ligazakon.net Retrieved from https://verdictum.ligazakon.net/document/94022453 [in Ukrainian]. 
22. Postanova Verhovnogo Sudu vid 22.07.2021 u spravi № 520/480/20 [Resolution of the Supreme Court of 22.07.2021 in the case № 520/480/20]. verdictum.ligazakon.net Retrieved from https://verdictum.ligazakon.net/document/98493729 [in Ukrainian].

23. Sudova sprava № 160/4272/21 [Court case № 160/4272/21]. vkursi.pro Retrieved from https://vkursi.pro/vsudi/decision/95809672 [in Ukrainian].

24. Sudova sprava № 420/7340/21 [Court case № 420/7340/21]. vkursi.pro Retrieved from https://vkursi.pro/vsudi/decision/96795462 [in Ukrainian].

25. Sudova sprava № 420/8714/21 [Court case № 420/8714/21]. vkursi.pro Retrieved from https://verdictum.ligazakon.net/document/97274817 [in Ukrainian]. 